\title{
Surgical Treatment of the Spinal Stenosis with an Interspinous Distraction Device: Do We Really Restore the Foraminal Height?
}

\author{
Bir Interspinöz Distraksiyon Cihaza ile Spinal Stenozun Cerrahi \\ Tedavisi: Gerçekten Foraminal Yüksekliği Restore Edebiliyor muyuz?
}

\author{
Haydar CELIK ${ }^{1}$, Alihan DERINCEK ${ }^{2}$, Ismet KOKSAL ${ }^{3}$ \\ ${ }^{1}$ M.H. Beypazart State Hospital, Department of Neurosurgery, Ankara, Turkey \\ ${ }^{2}$ Baskent University, Faculty of Medicine, Department of Orthopedics and Trauma, Adana, Turkey \\ ${ }^{3}$ High Specialised Hospital, Department of Orthopedics and Trauma, Kirikkale, Turkey
}

Correspondence address: Haydar CELIK / E-mail: dr_haydarcelik@hotmail.com

\begin{abstract}
AIM: The aim of implantation of interspinous device is to unload the facet joints, restore foraminal height and provide stability in order to improve the clinical outcome of surgery.

MATERIAL and METHODS: After microsurgical decompression, Coflex ${ }^{\mathrm{TM}}$ device was applied. Patients were evaluated at a month after surgery and last follow-up using the visual analogue scale (VAS) and Oswestry Disability Index (ODI). Foraminal height and lumbar lordosis angle were recorded.

RESULTS: The mean preoperative VAS was 7.85 and fell to 1.7 a month after surgery $(p<0.0001)$. At the last follow-up the mean VAS score was $1.65(p<0.0001)$. The mean foraminal heights were measured $19.95 \mathrm{~mm}$ preoperatively and $25.05 \mathrm{~mm}$ a month after surgery ( $<<0.0001$ ). The mean foraminal height was $21.60 \mathrm{~mm}$ at the last follow-up ( $=0.002)$. The mean lumbar lordosis were measured 32.05 and 34.3 degrees at preoperative and a month after surgery respectively $(p=0.155)$. The mean lumbar lordosis was $32( \pm 5.99)$ degrees at the last follow-up $(p=0.974)$.
\end{abstract}

CONCLUSION: Using the Coflex device is a minimal invasive, effective and safe procedure. Restoration of the foraminal height may not be a responsible factor for clinical improvement. We think microsurgical decompression looks responsible of the good clinical outcome and using interspinous device is unnecessary. Comparative clinical studies can be informative.

KEYWORDS: Interspinous device, Lumbar, Spinal stenosis, Foraminal height, Lordosis, Coflex

öz

AMAÇ: Interspinöz cihazları implante etmenin amacı faset eklemlere yüklenmemek, foraminal yüksekliği düzenlemek ve stabiliteyi sağlamak ve bu yollarla cerrahinin klinik sonuç başarısını artırmaktır.

YÖNTEM ve GEREÇ: Mikrocerrahi dekompresyon sonrası Coflex cihazı yerleştirildi. Hastalar cerrahiden sonra ayda bir değerlendirmeye alındı, Vizüel Analog Skala (VAS) ve Oswestry Dizabilite İndeks (ODi) ile takip edildi. Foraminal yükseklik ve lomber lordoz açıları da kaydedildi.

BULGULAR: Operasyon öncesi ortalama VAS 7.85, cerrahiden 1 ay sonra 1.7 idi $(p<0.0001)$. Son takipte ortalama VAS 1.65 idi $(p<0.0001)$. Operasyon öncesi ortalama foraminal yükseklik $19.95 \mathrm{~mm}$, cerrahiden 1 ay sonra $25.05 \mathrm{~mm}$ idi $(p<0.0001)$. Son takipte ortalama foraminal yükseklik $21.6 \mathrm{~mm}$ idi $(\mathrm{p}<0.0002)$. Operasyon öncesi ortalama lomber lordoz 32.05 derece, cerrahiden 1 ay sonra 34.3 derece idi $(p<0.0155)$. Son takipte ortalama lomber lordoz 32 dereceydi $( \pm 5.99)(p<0.974)$.

SONUÇ: Coflex implantı kullanımı minimal invaziv, etkili ve emniyetlidir. Bilinenin aksine foraminal yüksekliğin restorasyonu klinik düzelmeden sorumlu faktör olmayabilir. Mikrocerrahi dekompresyonun iyi klinik sonuç elde edilmesinde asıl faktör olduğu, interspinöz distraksiyon cihazı kullanımının gereksiz olabileceği düşünülmekle beraber, randomize klinik çalışmaların faydalı olacağı kanısına varılmıştır.

ANAHTAR SÖZCÜKLER: İnterspinöz cihaz, Lomber, Spinal stenoz, Foraminal yükseklik, Lordoz, Coflex

\section{INTRODUCTION}

Lumbar spinal stenosis is a reduction in the dimension of the central or lateral lumbar spinal canal that occurs most frequently as a result of chronic degenerative changes. Lumbar spinal stenosis is caused by degenerative changes of part of the spinal unit. Anatomically, the loss of disc height initiated subluxation of the articular processes. Sliding of the superior articular processes anteriorly causes the ligamentum flavum to bulge anteriorly and compressing the nerve root (1). Extension of the vertebral colon leads to bulging of the 
ligamentum flavum and posterior annulus fibrosus into the spinal canal, the lateral recesses and foramina. During maximal extension ligamentum flavum can become $2 \mathrm{~mm}$ thicker than in flexion $(5,6)$.

Spinal fusion is a common surgical technique for the treatment of the painful degenerative spinal disorders. The success rate of the fusion was reported as $16-95 \%$ (mean $68 \%$ ) in retrospective case series $(18,19,20)$. Spinal instrument improves the fusion rate but has no effect on short term clinical results (4) however; better clinical outcome reported with the instrument after 5 years (7). On the other side, increased morbidity and mortality risk has been shown with spinal fusion surgeries $(18,19)$. The fusion also eliminates the motion of the functional spinal unit and accelerates the degeneration of the adjacent segment $(3,9,11)$. To prevent complications and protect the adjacent segment, non-fusion surgical techniques have been enhanced.

Interspinous distraction device (IDD) applies between spinous process at the symptomatic level. The aims of implanting IDD were presented to unload the facet joints, restore foraminal height and provide stability especially in extension. The patient with neurogenic intermittent claudication who obtains relief on sitting and/ or flexion can be treated with IDD. The Coflex device (Spine motion, Germany) is a titanium spacer and implanted between spinous process. In this study we presented short term clinical and radiologic results of the Coflex IDD which implanted to the patients with spinal stenosis.

\section{MATERIAL and METHODS}

Between 2006-2008 years, patients with neurologic intermittent claudication, diagnosed as lumbar spinal stenosis and failed conservative treatment for 3 months were included in this study. After microsurgical decompression, Coflex ${ }^{\mathrm{TM}}$ IDD was applied. Clinical evaluations were performed preoperatively, a month after surgery and last follow-up using the visual analogue scale (VAS) and Oswestry Disability Index (ODI). Foraminal height and lumbar lordosis angle were also recorded at the same time. The foraminal height was measured as maximum distance between the inferior margin of the pedicle of the superior vertebra and superior margin of the pedicle of the inferior vertebra. The lumbar lordosis was measured as the angle between lines drawn parallel to the superior plate of L1 and the inferior plate of L5. Patients with marked degenerative spondylolisthesis ( $\geq 5 \mathrm{~mm}$ ), and isthmic spondylolisthesis were not included in study.

All comparisons were made at a statistical significance level of 0.05 or $95 \%$ confidence. Statistical analyses were performed using SPSS, version 10.0 (SPSS Inc., Chicago, IL, US).

\section{Surgical Technique}

Under general anesthesia patient was placed in prone position on surgical frame with neutral position or a slight kyphosis. Midline skin incision was performed at the appropriate level. The paraspinal muscles were sharply dissected with preserving the entire thickness of the supraspinous ligament. The facet capsules were also preserved. The supraspinous and the interspinous ligament were sacrificed and any bony overgrowth of the spinous process that may interfere with insertion is resected. Ligamentum flavum was then resected and microsurgical bilateral foraminotomy was performed. Microsurgical discectomy was applied if the patient suffered from radicular pain. After define appropriate implant size, the Coflex $^{\mathrm{TM}}$ IDD was placed in interspinous space with amount of interspinous distraction. In this instance, to ensure proper depth of implant insertion a small portion of the laminar surface may need partial resurfacing. Proper depth is determined if a beaded tip probe can be passed freely leaving 3-4 $\mathrm{mm}$ separation from the dura. The implant was fixed through two bone holes in the spinous process (Figure 1, 2). Skin is closed in the usual manner.

\section{RESULTS}

A total of 20 patients ( 9 female and 11 male) with spinal stenosis were included in the study. The mean age was 60 (range 47-74). In 4 patients, L3-L4 level and in 16 patients, L4-L5 level was implanted. Six patients who had radicular pain were also underwent microdiscectomy due to the disc herniation (Table I). The mean follow-up period was 11.8 months (6-18). The mean preoperative VAS was $7.85( \pm 0.75)$ and fell to 1.7 $( \pm 0.73)$ a month after surgery $(p<0.0001)$. At the last follow-up the mean VAS score was $1.65( \pm 0.49)(p<0.0001)$. There was also no statistical difference between early postoperative (1 month) and last follow-up VAS scores $(p=0.716)$. The mean preoperative ODI was $84.9( \pm 3.58)$ and fell to $12.9( \pm 2.10)$ a month after surgery $(p<0.0001)$. The mean ODI score was 12.2 $( \pm 1.28)$ at the last follow-up $(p<0.0001)$. There was also no statistical difference between early postoperative (1 month) ODI and last follow-up ODI scores $(p=0.130)$. Both VAS and ODI are reduced postoperatively, and this effect remained quite stable throughout the follow-up period.

The mean foraminal heights were measured $19.95 \mathrm{~mm}( \pm 2.35)$ and $25.05( \pm 2.24) \mathrm{mm}$ at preoperative and a month after surgery respectively $(p<0.0001)$. The mean foraminal height was $21.60( \pm 2.70) \mathrm{mm}$ at last follow-up $(p=0.002)$. There was also statistical difference between early postoperative (1 month) and last follow-up foraminal heights $(p<0.0001)$. The mean lumbar lordosis were measured $32.05( \pm 7.05)$ and 34.3 ( \pm 7.77$)$ degrees at preoperative and a month after surgery respectively $(p=0.155)$. The mean lumbar lordosis was 32 $( \pm 5.99)$ degrees at last follow-up $(p=0.974)$. There was also no statistical difference between early postoperative (1 month) and last follow-up lumbar lordosis $(\mathrm{p}<0.105)$.

No major complication was occurred. Superficial wound infection was treated with antibiotherapy in a case and dural tear was treated with myofascial flap in another case. No implant-related complication was occurred.

\section{DISCUSSION}

Historically, failure of the conservative treatment of the lumbar spinal stenosis was an indication for surgical 
Table I: Clinical and Radiological Outcomes of the Patients

\begin{tabular}{|c|c|c|c|c|c|c|c|c|c|c|c|c|c|}
\hline \multirow{2}{*}{ Age } & \multirow{2}{*}{ Sex } & \multirow{2}{*}{ Level } & \multirow{2}{*}{ disct } & \multicolumn{3}{|c|}{ VAS } & \multicolumn{3}{|c|}{ ODI } & \multicolumn{2}{|c|}{ Foraminal Height } & \multicolumn{2}{|c|}{ Lumbar Lordosis } \\
\hline & & & & Pre & $1 \mathrm{mt}$ & $\mathbf{F U}$ & Pre & $1 \mathrm{mt}$ & $\mathbf{F U}$ & Pre & FU & Pre & $\mathbf{F U}$ \\
\hline 49 & $E$ & L4-5 & + & 8 & 2 & 2 & 86 & 14 & 12 & 17 & 19 & 33 & 21 \\
\hline 47 & $E$ & L4-5 & + & 9 & 1 & 1 & 92 & 12 & 12 & 19 & 20 & 31 & 36 \\
\hline 62 & $E$ & L4-5 & + & 8 & 1 & 1 & 82 & 12 & 14 & 21 & 25 & 26 & 28 \\
\hline 66 & $\mathrm{~K}$ & L4-5 & + & 8 & 2 & 2 & 88 & 12 & 12 & 17 & 17 & 40 & 38 \\
\hline 54 & $\mathrm{~K}$ & L4-5 & + & 8 & 2 & 2 & 88 & 14 & 12 & 22 & 23 & 34 & 36 \\
\hline 58 & $E$ & L4-5 & + & 9 & 3 & 2 & 90 & 16 & 14 & 19 & 26 & 49 & 40 \\
\hline 66 & $\mathrm{~K}$ & L4-5 & & 7 & 2 & 2 & 84 & 14 & 12 & 20 & 21 & 42 & 40 \\
\hline 48 & $\mathrm{~K}$ & L3-4 & & 7 & 1 & 2 & 80 & 12 & 12 & 17 & 18 & 32 & 30 \\
\hline 68 & $E$ & L4-5 & & 7 & 1 & 1 & 82 & 10 & 12 & 18 & 18 & 28 & 27 \\
\hline 72 & $E$ & L3-4 & & 8 & 3 & 2 & 88 & 14 & 12 & 18 & 23 & 25 & 18 \\
\hline 65 & $E$ & L3-4 & & 7 & 2 & 2 & 84 & 12 & 12 & 21 & 21 & 24 & 34 \\
\hline 66 & $E$ & L4-5 & & 7 & 1 & 2 & 86 & 10 & 10 & 20 & 21 & 42 & 36 \\
\hline 50 & $\mathrm{~K}$ & L3-4 & & 8 & 1 & 1 & 86 & 12 & 12 & 19 & 24 & 34 & 30 \\
\hline 66 & $\mathrm{~K}$ & L4-5 & & 7 & 1 & 1 & 80 & 12 & 12 & 17 & 20 & 32 & 30 \\
\hline 74 & $E$ & L4-5 & & 9 & 3 & 2 & 86 & 18 & 14 & 23 & 24 & 28 & 32 \\
\hline 62 & $\mathrm{~K}$ & L4-5 & & 9 & 1 & 2 & 88 & 12 & 12 & 23 & 24 & 30 & 30 \\
\hline 65 & $E$ & L4-5 & & 8 & 2 & 2 & 82 & 12 & 12 & 24 & 25 & 27 & 28 \\
\hline 54 & $\mathrm{~K}$ & L4-5 & & 7 & 2 & 2 & 78 & 14 & 14 & 21 & 20 & 19 & 38 \\
\hline 51 & $E$ & L4-5 & & 8 & 1 & 1 & 84 & 10 & 10 & 24 & 24 & 31 & 30 \\
\hline 60 & $\mathrm{~K}$ & L4-5 & & 8 & 2 & 2 & 84 & 16 & 10 & 19 & 19 & 34 & 38 \\
\hline
\end{tabular}

VAS: Visual analogue Scale, ODI: Oswestry Disability Index, Pre: Preoperative, mt: month, FU: Follow-up, Disct: Discectomy

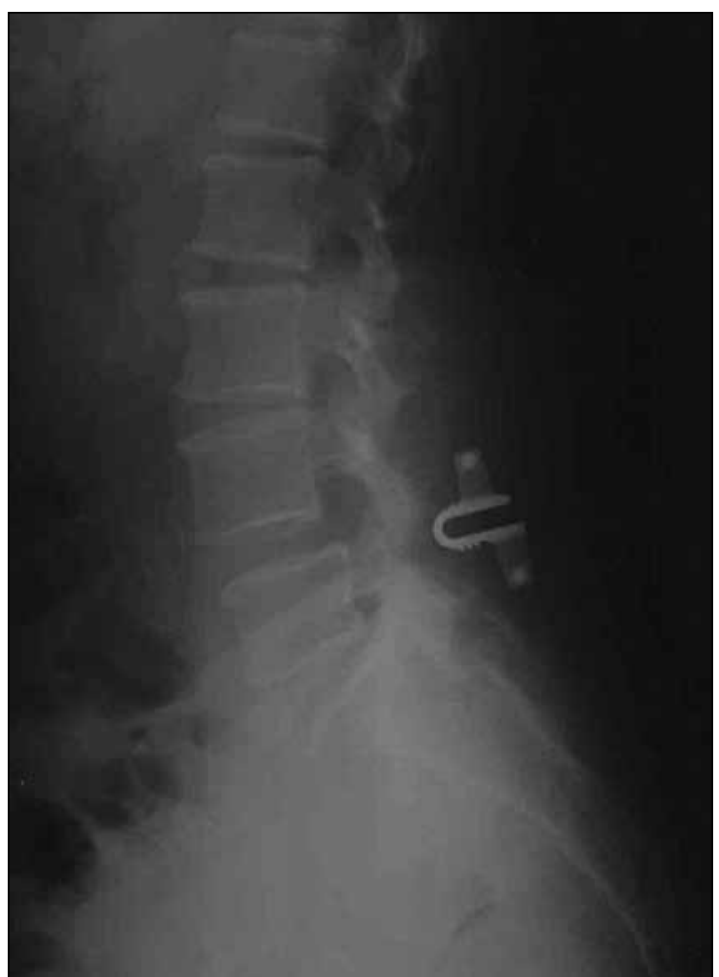

Figure 1: Lateral lumbosacral graph shows metallic opacity of the Coflex device implanted at L4-L5 level.

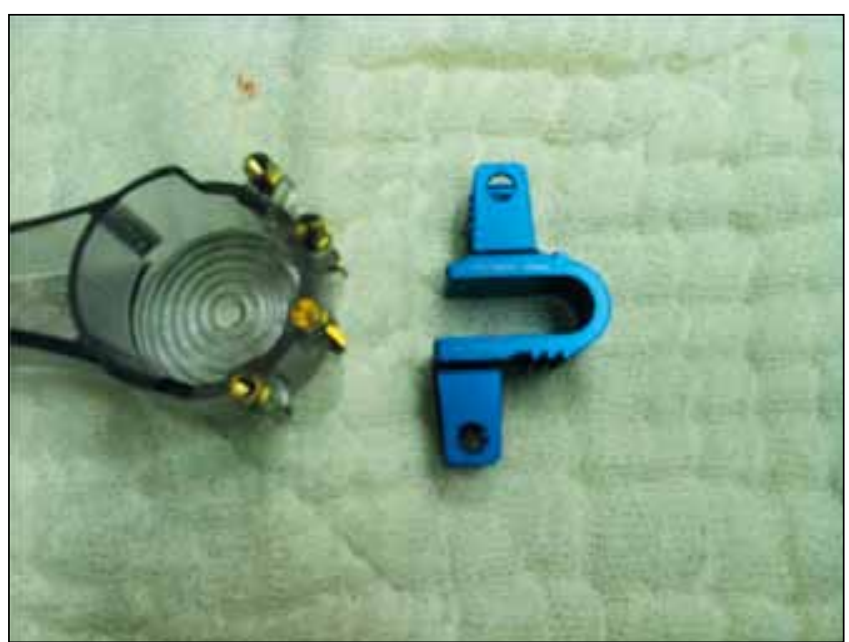

Figure 2: The Coflex device with fixation screws.

decompression by laminectomy with or without fusion. Nowadays, microsurgical decompression is preferred surgical technique for patient with severe spinal stenosis and leg pain. Interspinosus distraction devices are an alternative treatment technique beside microsurgical decompression in selected cases. Biomechanically, these types of devices constrained the extension but no effects on flexion, axial rotation or bending $(10,22)$. Some studies are claimed to that the IDD unload 
the facet joints and decrease intervertebral disc pressure $(10,12,15,22)$. Biomechanical studies are also shown that the IDD have no significant effect on adjacent segment intradiscal pressure and motion $(10,16,23)$. Wilke et al. (22) compared four different interspinous implants--Colfex, Wallis, Diam and $X$-Stop--in terms of their three-dimensional flexibility and the intradiscal pressure. They found that all tested interspinous implants had a similar effect on the flexibility and reduced the intradiscal pressure in extension, but had almost no effect in flexion, lateral bending and axial rotation. Tsai et al. (17) tested coflex IDD with partially destabilised human cadaveric specimens and concluded that the Coflex offers non-rigid fixation and can return a partially destabilized specimen back to the intact condition in terms of motion in flexion/extension and axial rotation.

In current study, 20 cases with one level spinal stenosis treated with the Coflex IDD were examined. At the mean 1 year follow-up, all the patients had significantly better clinical results. A prospective randominized multicenter study was published by Zuckerman et al. (24) showed that 59\% (100 cases) of success rate with an interspinous implant (X-stop) in 1 year after surgery. This result was much better than that of $12 \%$ in the control patients (91 cases) who were treated conservatively. A year later, Zuckerman et al. (25) published their 2 years follow-up that $73.1 \%$ of succes rate with X-stop and $35.9 \%$ in control patients. Kong et al. (8) compared to Coflex IDD and posterior lumbar interbody fusion (PLIF) in degenerative spinal stenosis with segmental instability. The clinical outcome was similar, however, the range of motion at the upper adjacent segments increased significantly after surgery in the PLIF group, which was not manifested in the Coflex group during the follow-up.

Interspinous distraction devices provide restoration of the foraminal height and canal area. Siddiqui et al. (13) showed significant increase in the dimension of the neural foramen and canal area using the positional magnetic resonance image in standing, sitting and supine flexion and extension after one or two level X-stop IDD implantation. Using the Coflex IDD, we achieved mean $25.5 \%$ foraminal height restoration after surgery. However at the last follow-up, the mean foraminal height was decreased to $8 \%$ of the mean preoperative value. The increased foraminal height values were reverted to preoperative values during follow-up period but the improved clinical outcome was not changed. The similar results were reported recently by Sobottke et al. (14). Retrospectively, they compared the clinical and radiologic results of the 3 different IDDs (X-stop, Wallis, Diam). The foraminal height, width and foraminal cross sectional area were significantly increased after surgery with all devices but progressively decreased during follow-up. They also reported that the X-stop group showed a significantly larger change foraminal height and foraminal cross sectional area than the Wallis and Diam IDDs. Although the X-stop IDD was achieved mean $17 \%$ foraminal height restoration after surgery, the percent of foraminal height restoration were decreased to $9.2 \%$ and $5.6 \%$ at 7 (mean follow-up 1) and 17 months (mean follow-up 2) respectively. These results has been given rise to thought that the restoration of the foraminal height or cross sectional area may improve the initial clinical outcome, however both parameters do not appear to be a main factor for patient satisfaction.

We also observed that the Coflex IDD does not affect on lumbar lordosis. The postoperative lumbar lordosis was slightly increased after surgery but changes were not significant. Crawford et al. (2) reported slight flattening of the segmental angle and regional lordosis after Diam IDD. However, serial clinical studies of spinal curvature after surgery with IDDs are warranted in order to better understand the effect of the IDD on lumbar lordosis.

\section{CONCLUSION}

Using the Coflex device in patients with lumbar spinal stenosis is a minimal invasive, effective and safe procedure. Clinical symptoms were improved after surgery and maintained throughout the 1 year follow-up period. Contrary to known, restoration of the foraminal height may not be a responsible factor for clinical improvement. We think that the microsurgical decompression looks responsible of the good clinical outcome and using interspinous distraction device is unnecessary. Comparative clinical studies can be more informative.

\section{REFERENCES}

1. Cinotti G, De Santis P, Nofroni I, Postacchini F: Stenosis of lumbar intervertebral foramen: Anatomic study on predisposing factors. Spine 27: 223-229, 2002

2. Crawford RJ, Price RI, Singer KP: The effect of interspinous implant surgery on back surface shape and radiographic lumbar curvature. Clin Biomech (Bristol, Avon) 24: 467-472, 2009

3. Derincek A, Mehbod A, Pinto M, Transfeldt E: Degeneration of non-fused segments after floating lumbar fusion. Acta Orthop Belg 74: 507-511, 2008

4. Fischgrund JS, Mackay M, Herkowitz HN, Brower R, Montgomery DM, Kurz LT: 1997 volvo award winner in clinical studies. Degenerative lumbar spondylolisthesis with spinal stenosis: A prospective, randomised study comparing decompressive laminectomy and arthrodesis with and without spinal instrumentation. Spine 22: 2807-2812, 1997

5. Fujiwara A, An HS, Lim TH, Haughton WM: Morphologic changes in the lumbar intervertebral foramen due to flexionextension, lateral bending, and axial rotation: An in vitro anatomic and biomechanical study. Spine 26: 876-882, 2001

6. Jenis LG, An HS: Spine update. Lumbar foraminal stenosis. Spine 25: 389-394, 2000

7. Kornblum MB, Fischgrund JS, Herkowitz HN, Abraham DA, Berkower DL, Ditkoff JS: Degenerative lumbar spondylolisthesis with spinal stenosis: A prospective longterm study comparing fusion and pseudoarthrosis. Spine 29: 726-33, 2004 
8. Kong DS, Kim ES, Eoh W: One-year outcome evaluation after interspinous implantation for degenerative spinal stenosis with segmental instability. J Korean Med Sci 22: 330-335, 2007

9. Kumar $\mathrm{MN}$, Jacquot $\mathrm{F}$, Hall $\mathrm{H}$ : Long-term follow-up of functional outcomes and radiographic changes at adjacent levels following lumbar spine fusion for degenerative disc disease. Eur Spine J 10: 309-313, 2001

10. Minns RJ, Walsh WK: Preliminary design and experimental studies of a novel soft implant for correcting sagittal plane instability in the lumbar spine. Spine 22: 1819-1825, 1997

11. Schlegel JD, Smith JA, Schleusener RL: Lumbar motion segment pathology adjacent to thoracolumbar, lumbar and lumbosacral fusions. Spine 21: 970-981, 1996

12. Senegas J: Mechanical supplementation by non-rigid fixation in degenerative intervertebral lumbar segments: The Wallis system. Eur Spine J 11 (suppl 2): 164-169, 2002

13. Siddiqui M, Karadimas E, Nicol M, Smith FW, Wardlaw D: Influence of X-stop on neural foramina and spinal canal area in spinal stenosis. Spine 31: 2958-2962, 2006

14. Sobottke R, Brust KS, Kaulhausen T, Röllinghoff $M$, Joswig $B$, Stützer H, Eysel P, Simons P, Kuchta J: Interspinous implants (X Stop, Wallis, Diam) for the treatment of the LSS: Is there a correlation between radiological parameters and clinical outcome? Eur Spine J 18: 1494-1503, 2009

15. Stoll TM, Dubois G, Schwarzenbach O: The dynamic neutralisation system for the spine: A multi-center study of a novel non-fusion system. Eur Spine J 11(Suppl): 170-178, 2002

16. Swanson KE, Lindsey DP, Hsu KY, Zucherman JF, Yerby SA: The effects of interspinous implant on intervertebral disc pressures. Spine 28: 26-32, 2003
17. Tsai KJ, Murakami H, Lowery GL, Hutton WC: A biomechanical evaluation of an interspinous device (Coflex) used to stabilize the lumbar spine. J Surg Orthop Adv 15:167-172, 2006

18. Turner JA, Herron L, Deyo RA: Meta-analysis of the results of lumbar spine fusion. Acta Orthop Scand (Suppl 251) 64: 120-122,1993

19. Turner JA, Ersek M, Herron L, Deyo R: Patient outcomes after lumbar spinal fusions. JAMA 268: 907-911, 1992

20. Turner JA, Ersek M, Herron L, Haselkorn J, Kent D, Ciol M, Deyo R: Surgery for lumbar spinal stenosis: Attempted metaanalysis of the literature. Spine 17:1-8, 1992

21. Verbiest $H$ : A radicular syndrome from developmental narrowing of the lumbar vertebral canal. J Bone Joint Surg 36B: 230-237, 1954

22. Wilke HJ, Drumm J, Haussler K, Mack C, Steudel WI, Kettler A: Biomechanical effect of different lumbar interspinous implants on flexibility and intradiscal pressure. Eur Spine J 17: 1049-1056, 2008

23. Wiseman CM, Lindsey DP, Fredrick AD, Yerby SA: The effect of an interspinous process implant on facet loading during extension. Spine 30: 903-907, 2005

24. Zucherman JF, Hsu KY, Hartjen CA, Mehalic TF, Implicito DA, Martin MJ, Johnson DR 2nd, Skidmore GA, Vessa PP, Dwyer JW, Puccio S, Cauthen JC, Ozuna RM: A prospective randomized multicenter study for the treatment of lumbar spinal stenosis with the X-STOP interspinous implant: 1-year results. Eur Spine J 13: 22-31, 2004

25. Zucherman JF, Hsu KY, Hartjen CA, Mehalic TF, Implicito DA, Martin MJ, Johnson DR 2nd, Skidmore GA, Vessa PP, Dwyer JW, Puccio ST, Cauthen JC, Ozuna RM: A multicenter, prospective, randomised trial evaluating the $X$ Stop interspinous process decompression system for the treatment of neurogenic intermittent claudication: Two year follow-up results. Spine 30:1351-1358, 2005 